\title{
Primary Langerhans Cell Histiocytosis of the Extrahepatic Bile Duct Occurring in an Adult Patient
}

\author{
Ifeyinwa E. Obiorah, Alicia Henao Velasquez, Bhaskar Kallakury, Metin Özdemirli
}

Department of Pathology, Medstar Georgetown University Hospital, Washington, USA

Background: Langerhans cell histiocytosis is characterized by an abnormal proliferation of neoplastic Langerhans cells. Langerhans cell histiocytosis commonly affects the pediatric population, whereas presentation in adults remains a rare event. The presentation of Langerhans cell histiocytosis is highly variable, but the involvement of skin, bone, and lung is very common. Langerhans cell histiocytosis presenting as a bile duct mass is rare and usually occurs as part of a multiorgan system disease.

Case Report: We present a case of Langerhans cell histiocytosis confined to the extrahepatic bile duct in a 62 -year-old female patient with sclerosing cholangitis. The mass was composed of mononuclear cells with cleaved nuclei that were positive for $\mathrm{CD} 68, \mathrm{~S} 100$, and CD1a as assessed by immunohistochemistry.

Conclusion: This is the first report of Langerhans cell histiocytosis limited to the extrahepatic bile duct in an adult patient. We discuss the clinical manifestations and the challenges encountered in the diagnosis and treatment of this rare entity.

Keywords: Bile duct, histiocytosis, Langerhans cell, sclerosing cholangitis
Langerhans cell histiocytosis (LCH), formerly known as histiocytosis $\mathrm{X}$, is a wide spectrum of clinical disorders involving abnormal accumulation of Langerhans cells in various organs. Langerhans cells are derived from the dendritic cells, which are typically found in the epidermis and function as antigen-presenting cells to the immune system. Proliferation of abnormal Langerhans cells, which are closely related to histiocytes, in either singleorgan or multiorgan system can result in organ dysfunction (1). Depending on the extent of involvement, $\mathrm{LCH}$ can result in benign or life-threatening morbid outcomes (2). $\mathrm{LCH}$ is a rare disease and is primarily observed in pediatric patients, with $50 \%-90 \%$ of cases being diagnosed between the ages of 1 and 15 years $(2,3)$. Adults are rarely affected. The clinical manifestation of LCH is heterogeneous, based on which it can be classified as single organ or multiorgan system disease. The involvement of skin, lungs, and bone is common in single organ disease. Liver and bile duct involvement is usually observed in the disseminated form of LCH. Primary LCH of the extrahepatic bile duct is a rare event and, to date, only one case has been described in the pediatric population. To the best of our knowledge, LCH confined to the bile duct has never been reported in an adult patient. Here we describe a unique presentation of $\mathrm{LCH}$ presenting as a solitary lesion limited to the extrahepatic bile duct in an adult female patient.

\section{CASE PRESENTATION}

A 62-year-old female patient was referred to our institution for further diagnostic workup of elevated liver enzymes and incidental cholelithiasis. She complained of worsening jaundice, nausea and vomiting, dark urine, and a 25-pound weight loss at the time of admission. Liver function results were as follows: aspartate aminotransferase $43 \mathrm{U} / \mathrm{L}$ and alanine aminotransferase $53 \mathrm{U} / \mathrm{L}$, alkaline phosphatase $442 \mathrm{U} / \mathrm{L}$, albumin $3.2 \mathrm{~g} / \mathrm{dL}$, bilirubin total 2.5 $\mathrm{mg} / \mathrm{dL}$, and bilirubin direct $1.5 \mathrm{mg} / \mathrm{dL}$. An endoscopic retrograde cholangiopancreatography showed strictures of the common bile duct suggestive of primary sclerosing cholangitis. A contrast-enhanced computed tomography scan (Figure 1) revealed an ill-defined, lowattenuating soft tissue mass in the porta hepatis with biliary duct dilatation, but no intrahepatic mass was identified. Based on these findings, a preoperative diagnosis of cholangiocarcinoma secondary to primary sclerosing cholangitis was made. The patient underwent a common bile duct resection, cholecystectomy, and Roux-en-Y hepaticojejunostomy. The mass was completely removed and sent to pathology for confirmatory diagnosis. Histologic sections of the left and the right bile ducts showed a histiocytic cell proliferation that consisted of mononuclear bean-shaped cells with cleaved nuclei and abundant cytoplasm admixed with eosinophils (Figure

\footnotetext{
Address for Correspondence: Dr. Ifeyinwa E. Obiorah, Department of Pathology, Georgetown University Medical Center, Washington, USA Phone: 2023843639 e-mail: Ifeyinwa.e.obiorah@gunet.georgetown.edu ORCID ID: orcid.org/0000-0001-6285-7382

Received: 18 December 2017 Accepted: 2 March 2018 •DOI: 10.4274/balkanmedj.2017.1730

Available at www.balkanmedicaljournal.org

Cite this article as:

Obiorah IE, Henao Velasquez A, Kallakury B, Özdemirli M. Primary Langerhans Cell Histiocytosis of the Extrahepatic Bile Duct Occurring in an Adult Patient. Balkan Med J 2018;35:437-9

${ }^{\circ}$ Copyright 2018 by Trakya University Faculty of Medicine / The Balkan Medical Journal published by Galenos Publishing House.
} 
$2 \mathrm{a}, 2 \mathrm{~b})$. Sections of the adjacent liver showed variable bile duct proliferation, focal bridging and periductal fibrosis, and cholestasis. Immunohistochemistry revealed neoplastic cells that were positive for S100 (Figure 2c), CD1a (Figure 2d), CD68, CD14, and lysozyme. Electron microscopy of the tumor cells demonstrated the presence of Birbeck granules (Figure 2e) in the majority of histiocytes examined. These findings confirmed the diagnosis of LCH. The patient underwent a whole-body imaging to look for other areas of disease involvement, but the studies were negative. The patient received adjuvant chemotherapy with 5 courses of cladribine and was disease-free for 14 months after which she developed bacteremia due to a polymicrobial biliary infection from a chronic indwelling biliary drain. On admission, imaging studies did not reveal any evidence of malignancy. The

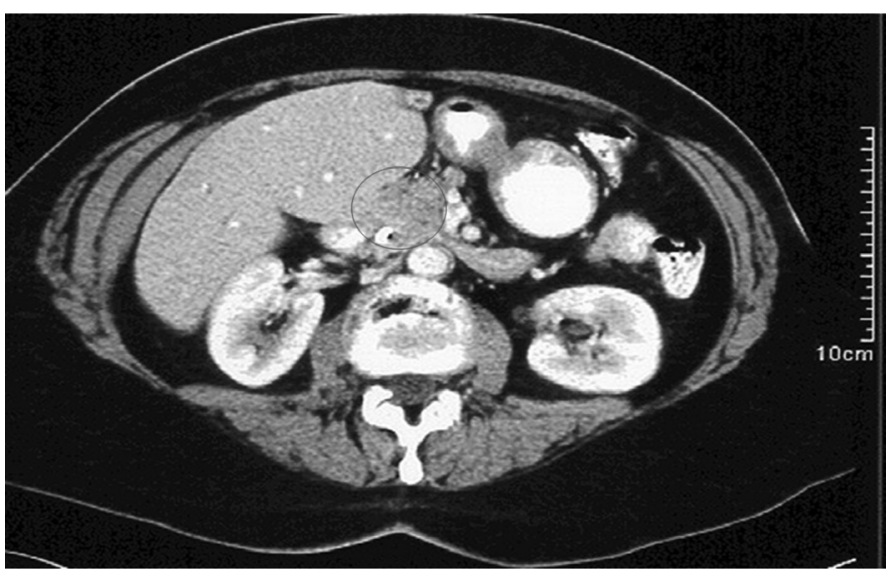

FIG. 1. Computed tomography scan of the bile duct mass. The image shows an enhancing mass in the porta hepatis. patient went into septic shock, and despite therapeutic measures with antibiotics, vasopressor support, and volume resuscitation, she expired. An institutional review board waiver of consent was obtained for publishing the case report.

\section{DISCUSSION}

LCH consists of a constellation of clinical presentations, which include Letterer-Siwe syndrome, a multisystem disease of young children characterized by cutaneous lesions containing infiltrates of Langerhans cells and a poor prognosis; eosinophilic granuloma, a solitary bone lesion; and Hand-Schuller-Christian disease that manifests as a characteristic triad of cranial bone lesions, diabetes insipidus, and exophthalmos (2). LCH can affect any organ or system in the body, but those more commonly affected are bone $(80 \%)$, skin $(33 \%)$, pituitary gland $(25 \%)$, lungs $(15 \%)$, liver $(15 \%)$, the hematopoietic system $(15 \%)$, lymph nodes $(5 \%-10 \%)$, and the central nervous system excluding the pituitary gland $(2 \%-4 \%)(4)$. The natural history of the disease is also extremely variable, ranging from a self-remitting lesion to a disease involving several organs with life-threatening consequences.

LCH involvement of the bile duct can occur, but it usually presents in the disseminated form of the disease and the prognosis is very poor $(5,6)$. LCH of the bile duct can present with progressive destruction leading to sclerosing cholangitis and eventually to secondary biliary cirrhosis (7-9). Primary LCH of the extrahepatic bile duct is very rare. Prior to our report, only one case has been reported in a 2.5-year-old female patient (10). A review of both cases showed that primary LCH of the bile duct presents as a solitary mass with clinical signs and symptoms of obstructive jaundice. Common sequelae of the mass appear to be sclerosing cholangitis, and

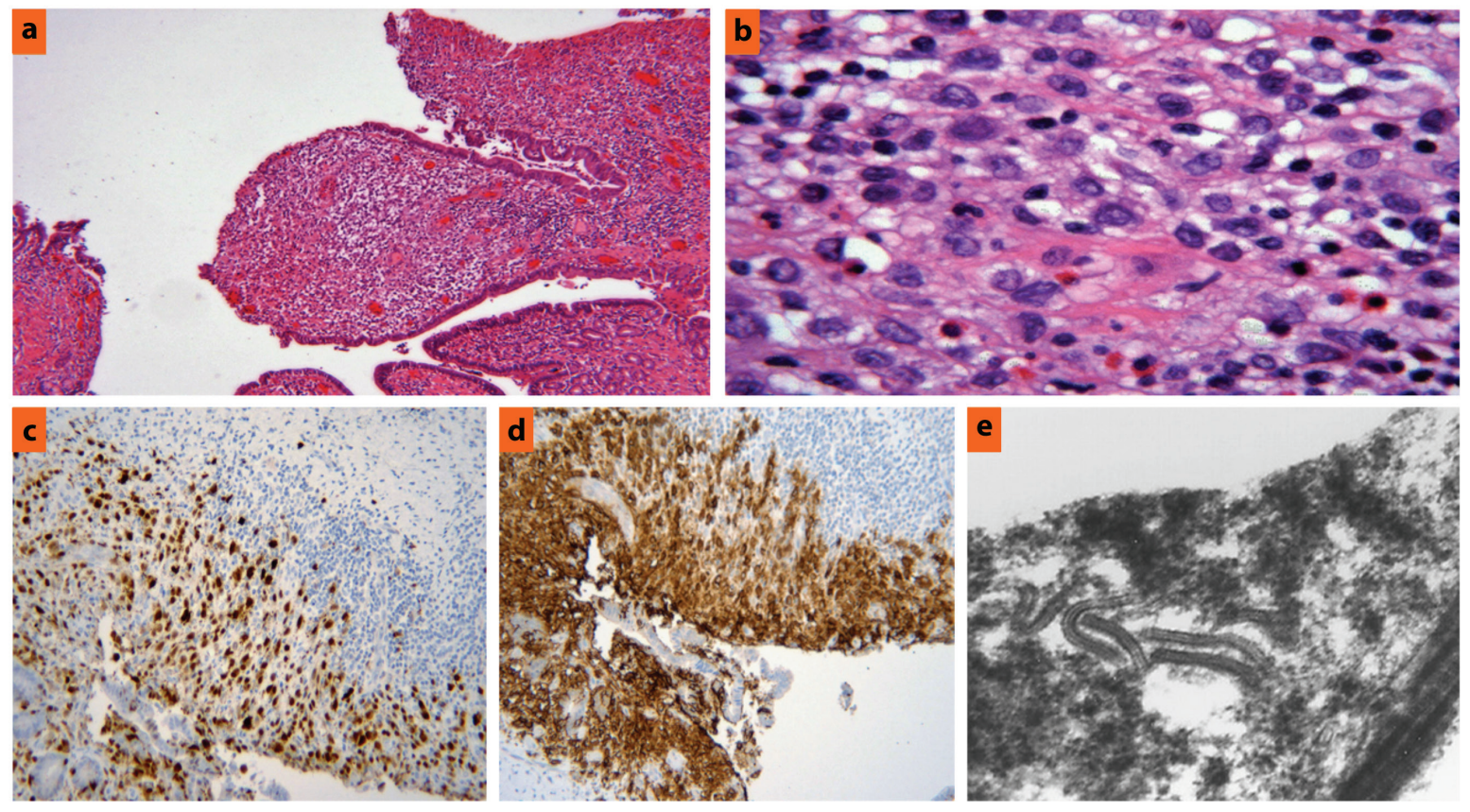

FIG. 2. a, e. Pathologic examination of the biliary mass. Mononuclear bean-shaped cells with cleaved nuclei and abundant cytoplasm admixed with eosinophils infiltrating the bile duct. Hematoxylin and eosin $\times 40$ (a), Hematoxylin and eosin $\times 400$ (b), Immunohistochemistry revealed atypical cells positive for S100 (c) and CD1a ( $\times 200$ each) (d), Electron microscopy of the infiltrating cells showed Birbeck granules in the cytoplasm (e). 
TABLE 1. Reported cases of primary Langerhans cell histiocytosis of the biliary system

\begin{tabular}{|c|c|c|c|c|c|c|c|c|c|}
\hline Case & $\begin{array}{l}\text { Age } \\
\text { (years) }\end{array}$ & Sex & Clinical presentation & $\begin{array}{c}\text { Clinical } \\
\text { association }\end{array}$ & $\begin{array}{l}\text { Focality of } \\
\text { the mass }\end{array}$ & $\begin{array}{c}\text { Positive } \\
\text { immunochemistry } \\
\text { markers }\end{array}$ & Treatment & $\begin{array}{c}\text { Recurrences/ } \\
\text { metastasis }\end{array}$ & $\begin{array}{l}\text { Follow-up } \\
\text { (months) }\end{array}$ \\
\hline $\begin{array}{l}1 \\
(10)\end{array}$ & 2.5 & Female & $\begin{array}{l}\text { Obstructive jaundice, } \\
\text { hepatosplenomegaly, } \\
\text { ascites, pruritus }\end{array}$ & $\begin{array}{l}\text { Primary } \\
\text { sclerosing } \\
\text { cholangitis }\end{array}$ & Solitary & CD1a, S100 & $\begin{array}{c}\text { Liver } \\
\text { transplantation }\end{array}$ & None & $\begin{array}{l}\text { Alive, } 2 \\
\text { years }\end{array}$ \\
\hline $\begin{array}{l}\text { Our } \\
\text { case }\end{array}$ & 62 & Female & $\begin{array}{l}\text { Obstructive jaundice, } \\
\text { nausea and vomiting, } \\
\text { dark urine, weight loss }\end{array}$ & $\begin{array}{l}\text { Primary } \\
\text { sclerosing } \\
\text { cholangitis }\end{array}$ & Solitary & CD1a, S100, CD68 & $\begin{array}{l}\text { Common bile duct } \\
\text { resection+cladribine }\end{array}$ & None & $\begin{array}{l}\text { Died of } \\
\text { sepsis, } 14 \\
\text { months }\end{array}$ \\
\hline
\end{tabular}

both were diagnosed on a cholangiogram. Some reports suggest that the presence of sclerosing cholangitis, especially in children, should raise a suspicion for LCH $(11,12)$. However, these studies included cases of disseminated LCH involving the hepatobiliary system, and involvement of the extrahepatic bile duct in these cases was rare. The key to a definitive diagnosis of $\mathrm{LCH}$ of the bile duct depends on the morphologic identification of abnormal proliferation of mononuclear cells with bean-shaped cleaved nuclei, which are derived from myeloid progenitor cells of the bone marrow (1). Similar to Langerhans cells located in the skin, they express histiocytic markers such as S100, CD1a, and CD68 and contain Birbeck granules, which are rod-shaped intracytoplasmic organelles best demonstrated on electron microscopy.

Treatment of LCH depends on the extent of the disease and can range from observation, surgery, and radiotherapy to multimodal chemotherapy. However, the precise treatment of primary LCH of the bile duct remains unknown due to limited data. Successful treatment with orthotropic liver transplantation was demonstrated by Finn and Jaffe (10) in their 2.5-year-old patient; however, the long-term effect of the procedure was not determined. Although our patient was successfully treated with surgical resection of the common bile duct with biliary bypass and post-adjuvant chemotherapy with cladribine, she died from complications of sepsis. Therefore, more insight is needed to determine the best treatment of $\mathrm{LCH}$ confined to the extrahepatic bile duct.

In conclusion, $\mathrm{LCH}$ confined to the extrahepatic bile duct is a rare phenomenon that is challenging to diagnose both by the clinician and by the pathologist. A high clinical suspicion should have been raised in our adult female patient with sclerosing cholangitis with a solitary biliary mass. Early diagnosis and treatment is needed to improve the clinical outcome.
Conflict of Interest: No conflict of interest was declared by the authors.

Financial Disclosure: No financial disclosure was declared by the authors.

\section{REFERENCES}

1. Hage C, Willman CL, Favara BE, Isaacson PG. Langerhans' cell histiocytosis (histiocytosis X): Immunophenotype and growth fraction. Human Pathol 1993;24:8405 .

2. DiCaprio MR, Roberts TT. Diagnosis and management of langerhans cell histiocytosis. J Am Acad Orthop Surg 2014;22:643-52.

3. Maria Postini A, del Prever AB, Pagano M, Rivetti E, Berger M, Asaftei SD, et al. Langerhans cell histiocytosis: 40 years' experience. J Pediatr Hematol Oncol 2012;34:353-8.

4. Donadieu J, Chalard F, Jeziorski E. Medical management of langerhans cell histiocytosis from diagnosis to treatment. Expert Opin Pharmacother 2012;13:130922.

5. Leblanc A, Hadchouel M, Jehan P, Odievre M, Alagille D. Obstructive jaundice in children with histiocytosis X. Gastroenterol 1981;80:134-9.

6. Jaffe R. Liver involvement in the histiocytic disorders of childhood. Pediatr Dev Pathol 2004;7:214-25.

7. Navaneethan U, Parsi MA. Langerhans cell histiocytosis and choledocholithiasis: is there an association? Gastroenterol Hepatol (NY) 2012;8:768-9.

8. Hatemi I, Baysal B, Senturk H, Behzatoglu K, Bozkurt ER, Ozbay G. Adult Langerhans cell histiocytosis and sclerosing cholangitis: a case report and review of the literature. Hepatol Int 2010;4:653-8.

9. Braier J, Ciocca M, Latella A, de Davila MG, Drajer M, Imventarza O. Cholestasis, sclerosing cholangitis, and liver transplantation in Langerhans cell Histiocytosis. Med Pediatr Oncol 2002;38:178-82.

10. Finn LS, Jaffe R. Langerhans' cell granuloma confined to the bile duct. Pediatr Pathol Lab Med 1997; 17:461-8.

11. Jones MB, Voet R, Pagani J, Lotysch M, O'Connell T, Koretz RL. Multifocal eosinophilic granuloma involving the common bile duct: histologic and cholangiographic findings. Gastroenterol 1981;80:384-9.

12. Al Salloom AA, Almalki ST, Almana H, Burdelski M. Diabetes Insipidus and Sclerosing Cholangitis in a child may be a clue to the diagnosis of Langerhans' Cell Histiocytosis: A Case Report. Int J Health Sci (Qassim) 2013;7:248-51. 